\title{
An alloherpesvirus infection of European perch Perca fluviatilis in Finland
}

\author{
Kyle A. Garver ${ }^{1, *}$, Katja Leskisenoja ${ }^{2}$, Robert Macrae ${ }^{3}$, Laura M. Hawley ${ }^{1}$, \\ Kuttichantran Subramaniam ${ }^{4}$, Thomas B. Waltzek ${ }^{4}$, Jon Richard ${ }^{1}$, \\ Caroline Josefsson $^{3}$, E. Tellervo Valtonen ${ }^{\mp}$
}

\author{
${ }^{1}$ Fisheries and Oceans Canada, Pacific Biological Station, Nanaimo, British Columbia V9T 6N7, Canada \\ ${ }^{2}$ Department of Biological and Environmental Science, University of Jyväskylä, Jyväskylä 40014, Finland \\ ${ }^{3}$ Biology Department, Vancouver Island University, Nanaimo, British Columbia V9R 5S5, Canada \\ ${ }^{4}$ Department of Environmental and Global Health, College of Public Health and Health Professions, University of Florida, \\ Gainesville, Florida 32611, USA
}

\begin{abstract}
The order Herpesvirales includes viruses that infect aquatic and terrestrial vertebrates and several aquatic invertebrates (i.e. mollusks), and share the commonality of possessing a double-stranded DNA core surrounded by an icosahedral capsid. Herpesviruses of the family Alloherpesviridae that infect fish and amphibians, including channel catfish virus and koi herpesvirus, negatively impact aquaculture. Here, we describe a novel herpesvirus infection of wild European perch from lakes in Finland. Infected fish exhibited white nodules on the skin and fins, typically in the spring when prevalence reached nearly $40 \%$ in one of the sampled lakes. Transmission electron microscopic examination of affected tissues revealed abundant nuclear and cytoplasmic virus particles displaying herpesvirus morphology. Degenerate PCR targeting a conserved region of the DNA polymerase gene of large DNA viruses amplified a 520 bp product in 5 of 5 affected perch skin samples tested. Phylogenetic analysis of concatenated partial DNA polymerase and terminase (exon 2) gene sequences produced a well-supported tree grouping the European perch herpesvirus with alloherpesviruses infecting acipenserid, esocid, ictalurid, and salmonid fishes. The phenetic analysis of the European perch herpesvirus partial DNA polymerase and terminase nucleotide gene sequences ranged from 34.6 to $63.9 \%$ and 39.6 to $59.6 \%$ to other alloherpesviruses, respectively. These data support the European perch herpesvirus as a new alloherpesvirus, and we propose the formal species designation of Percid herpesvirus 2 (PeHV2) to be considered for approval by the International Committee on Taxonomy of Viruses.
\end{abstract}

KEY WORDS: Herpesvirus $\cdot$ European perch $\cdot$ White nodules $\cdot$ Alloherpesvirus

\section{INTRODUCTION}

European perch Perca fluviatilis are common in Europe and are especially well adapted to conditions in Finland, as indicated by their abundance and a successful fishery for this species in Finnish lakes. Of the nearly $47500 \mathrm{t}$ of freshwater fish harvested annually in Finland, approximately 27\% (13000 t) consists of wild European perch (Tribiloustova 2005). The capacity for European perch to tolerate acidic waters, utilize vari-

${ }^{*}$ Corresponding author: kyle.garver@dfo-mpo.gc.ca

${ }^{\ddagger}$ Deceased ous food resources, and reproduce effectively explains their success in colonizing Finnish lakes (Koli 1990).

The European perch is a popular species targeted by anglers. In early spring and summer months, recreational fishing efforts on 4 lakes in central Finland noted the occurrence of a disease manifested by the appearance of white nodules on the skin and fins of perch. Due to the high prevalence and abnormal appearance of the white nodules on fish, concern was raised among the fishermen and prompted this

() Fisheries and Oceans Canada, K.L., R.M., K.S., T.B.W., C.J., E.T.V. 2018. Open Access under Creative Commons by Attribution Licence. Use, distribution and reproduction are unrestricted. Authors and original publication must be credited. 
investigation to better understand the etiology and ecology of this disease.

The appearance of white nodules on the exterior of fish has been reported in a wide range of freshwater and marine species and has been attributed to various infectious causes including the ciliated protozoan parasite Ichthyophthirius multifiliis (Matthews 2005), lymphocystis disease virus (Anders 1989), and a herpes-like virus (Kelly et al. 1983). Notably, the herpes-like virus and lymphocystis disease virus were found in percid species in North America, specifically, herpes-like virus from walleye Stizostedion vitreum vitreum (Kelly et al. 1983) and lymphocystis disease virus from walleye and yellow perch Perca flavescens (Craig 2000, Palmer et al. 2012). In the absence of microscopic evidence of $I$. multifiliis in our investigations, laboratory studies were focused on identifying potential viral agents infecting the diseased European perch. Through the use of histological evaluation, transmission electron microscopy (TEM), and molecular analyses, we describe a novel herpesvirus infection associated with the formation of white nodules in European perch.

To date, herpesviruses infecting fish and amphibians have been placed taxonomically into the Alloherpesviridae family by the International Committee on Taxonomy of Viruses (ICTV 2012). Members of this family, such as channel catfish virus Ictalurid herpesvirus 1 (IcHV1) and koi herpesvirus Cyprinid herpesvirus 3 (CyHV3), can cause significant disease and mortality in aquaculture (Plumb \& Hanson 2011). Due to their disease-causing potential, full genome sequencing of several members of the Alloherpesviridae family has been completed. Analyses of the koi herpesvirus genome indicated the presence of 13 conserved core genes (Aoki et al. 2007, van Beurden et al. 2010). Yet a high degree of sequence diversity exists across the Alloherpesviridae family, with deduced amino acid sequence identities ranging from 27.7 to $90.6 \%$ within the DNA polymerase gene (Waltzek et al. 2009).

PCR methods have been used to amplify specific partial sequences of the DNA polymerase (Hanson et al. 2006), the ATPase subunit of the terminase gene (Waltzek et al. 2009), and the glycoprotein gene (Glenney et al. 2016). These sequences have subsequently been used to clarify phylogenetic relationships within the Alloherpesviridae family. Currently, this family consists of 4 genera: Batrachovirus, which includes viruses infecting frogs; Cyprinivirus, consisting of viruses that infect carp and eels; Ictalurivirus, with viruses that infect catfish and sturgeon; and lastly, Salmonivirus, representing herpesviruses that infect salmonids (Hanson et al. 2011, ICTV 2012). However, it is noteworthy that in addition to the viruses represented by these 4 genera, members of the Alloherpesviridae family have been detected in Siberian sturgeon Acipenser baerii (Doszpoly et al. 2017), walleye (Kelly et al. 1983), northern pike Esox lucius (Yamamoto et al. 1984), turbot Scophthalmus maximus (Hellberg et al. 2002), rainbow and European smelt Osmerus mordax and O. eperlanus (Morrison et al. 1996, Jakob et al. 2010), pilchard Sardinops sagax neopilchardus (Crockford et al. 2005), Pacific and Atlantic cod Gadus macrocephalus and G. morhua (McArn et al. 1978, McCain et al. 1979, Marcos-Lopez et al. 2012), Atlantic salmon Salmo salar (Doszpoly et al. 2013) and lake trout Salvelinus namaycush (Glenney et al. 2016) that have yet to be assigned taxonomic position by the ICTV (see Hanson et al. 2011 and van Beurden \& Engelsma 2012 for overview).

In the present investigation, we describe the temporal occurrence of white nodules associated with an alloherpesvirus infection of European perch. Given the novelty of finding an alloherpesvirus infection in European perch, we compared the genetic relationship of this new virus to other alloherpesviruses.

\section{MATERIALS AND METHODS}

\section{Study location and water metrics}

Perch were caught from 4 lakes in central Finland that include a large, deep lake, Lake Isojärvi (hereafter Lake 1) and 3 small forest lakes, Lake Murtonen, (Lake 2), Lake Ahvenjärvi (Lake 3), and Lake Iso Myllyjärvi (Lake 4) (Fig. 1). Water flows from Lake 4 into Lake 1 . The water flowing from Lake 1 is joined by water from Lake 3 and then by water from Lake 2 as it flows to Lake Päijänne and eventually to the Gulf of Finland. These 4 lakes are near each other in the same catchment area; Lake 2 is $3.9 \mathrm{~km}$ from Lake 4 (Table 1). At each lake, $\mathrm{pH}$, chemical oxygen demand $\left(\mathrm{COD}_{\mathrm{Mn}}\right)$, total phosphorous, iron, oxygen content, and temperature were measured in April 1998 from samples taken at a depth of $3 \mathrm{~m}$ with a Ruttnersampler. The $\mathrm{pH}$ was measured using a $\mathrm{pH}$ M83 standard $\mathrm{pH}$-meter, and $\mathrm{COD}_{\mathrm{Mn}}$, total phosphorous and iron were analyzed according to Finnish Standards Association SFS (SFS 3036, SFS 3026, SFS 3028). Lakes 1, 2, and 3 were oligotrophic, with total phosphorous values remaining below $11 \mathrm{\mu g} \mathrm{l}^{-1}$, except at Site E in Lake 1, where the value was $22 \mu \mathrm{g} \mathrm{l}^{-1}$ (Table 2). In Lakes 1, 2, and 3, the $\mathrm{COD}_{\mathrm{Mn}}$ was $<5 \mathrm{mg}$ 
Fig. 1. Location of the 4 lakes (1-4) studied in Central Finland in 1997 and 1998 for occurrence of white nodules in perch, Perca fluviatilis. Five sites (A-E) were studied in Lake Isojärvi

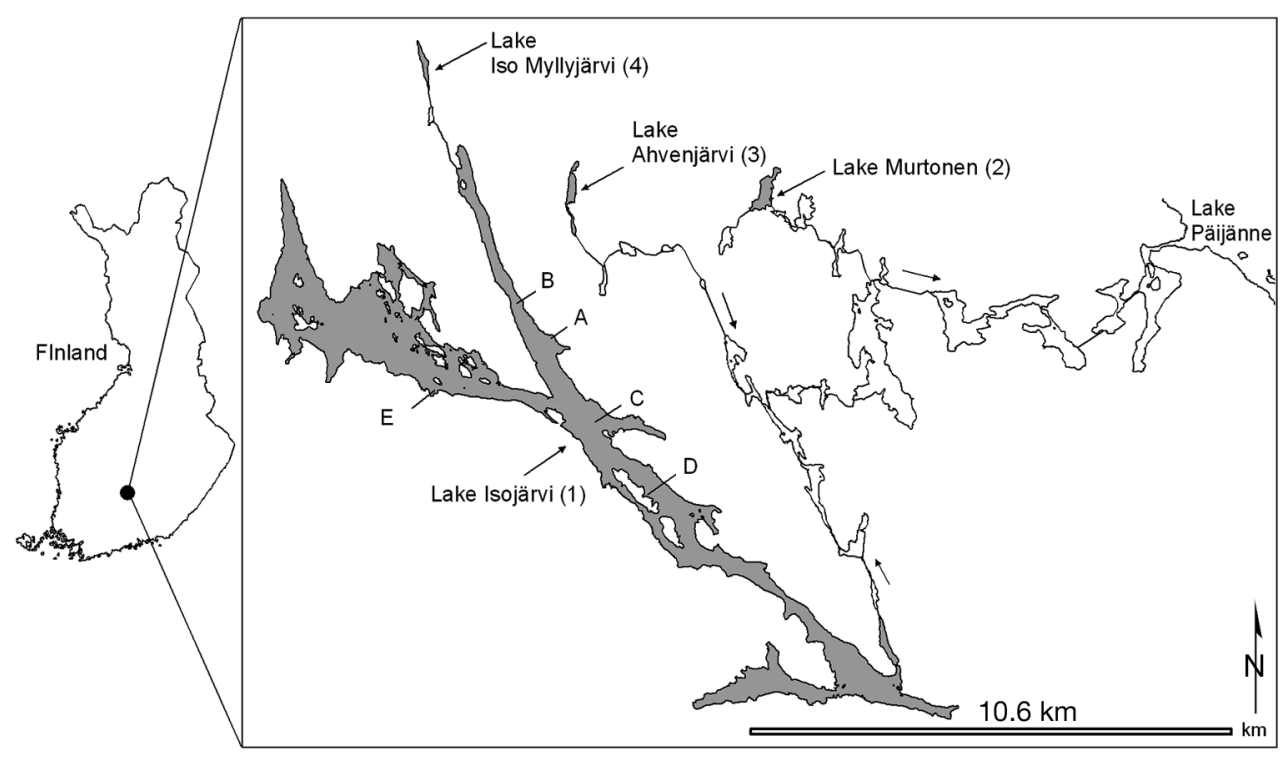

Table 1. Spatial characteristics of 4 lakes in central Finland where European perch were sampled (see Fig. 1). Distance is straight line distance from Lake 1

\begin{tabular}{|lccc|}
\hline Lake & $\begin{array}{c}\text { Area } \\
\text { (ha) }\end{array}$ & $\begin{array}{c}\text { Maximum } \\
\text { depth }(\mathrm{m})\end{array}$ & $\begin{array}{c}\text { Distance from } \\
\text { Lake 1 }(\mathrm{km})\end{array}$ \\
\hline 1 & 1833.8 & 69.7 & - \\
2 & 10.0 & 11.5 & 3.9 \\
3 & 17.0 & 16.0 & 1.8 \\
4 & 9.3 & 5.1 & 1.8 \\
\hline
\end{tabular}

$\mathrm{l}^{-1}$, and iron values were $<150 \mu \mathrm{g} \mathrm{l^{-1 }}$. Lake 4 was eutrophic, with low oxygen content $\left(5.1 \mathrm{mg} \mathrm{l}^{-1}\right)$ and iron values exceeding $1000 \mathrm{\mu g} \mathrm{l}^{-1}$. $\mathrm{COD}_{\mathrm{Mn}}$ was $27 \mathrm{mg} \mathrm{l}^{-1}$ and total phosphorous was $21 \mu \mathrm{g} \mathrm{l}^{-1}$. Each of the lakes was slightly acidic, with Lakes 1, 2, 3, and 4 having $\mathrm{pH}$ values of $5.8,6.3,5.3$, and 5.4 , respectively. to minimize size effects when comparing fish collected at different times and locations. The size of perch sampled represented an age at which fish are capable of being sexually mature. Each fish was euthanized by a quick blow to the head, and a count of white nodules (see 'Results: Gross pathology and histopathology') on the left side of each fish was tabulated. The severity of nodule formation was scored as low, moderate, or high based on the number of nodules present. Low severity was categorized as the occurrence of $<10$ nodules, moderate was from 10 to 30 , and high was $>30$. Statistical analyses of white nodule prevalence were made by the SPSS statistical program (IBM Analytics). Differences in prevalence (Bush et al. 1997) were tested by $\chi^{2}$-test and Wilcoxon match pairs test. A non-parametric test was used because the data were not normally distributed.

\section{Fish sampling}

A total of 745 perch were caught using either angling, ice-fishing, netting, or fish trapping. In May 1997 and 1998, 20 perch were caught from a single site from each of the 3 smaller lakes and from 5 sites in Lake 1. Additionally, during each month between May 1997 and May 1998, 20 perch were caught from each of Sites B and $\mathrm{C}$ in Lake 1 (Fig. 1). In 2012, perch were collected from Lake 1 solely for virological studies. The weights of perch sampled throughout the study were restricted to between 20 and $30 \mathrm{~g}$
Table 2. Lake water metrics of samples collected April 1998 at 3 m depth. $\mathrm{COD}_{\mathrm{Mn}}$ : chemical oxygen demand

\begin{tabular}{|lcccccc|}
\hline Site & $\begin{array}{c}\mathrm{COD}_{\mathrm{Mn}} \\
\left(\mathrm{mg} \mathrm{l}^{-1}\right)\end{array}$ & $\begin{array}{c}\text { Total } \\
\text { phosphorus } \\
\left(\mu \mathrm{I} \mathrm{l}^{-1}\right)\end{array}$ & $\begin{array}{c}\text { Oxygen } \\
\text { content } \\
\left(\mathrm{mg} \mathrm{l}^{-1}\right)\end{array}$ & $\mathrm{pH}$ & $\begin{array}{c}\text { Iron } \\
\left(\mu \mathrm{l} \mathrm{l}^{-1}\right)\end{array}$ & $\begin{array}{c}\text { Temp. } \\
\left({ }^{\circ} \mathrm{C}\right)\end{array}$ \\
\hline 1A & 5 & 10 & 12.3 & 6.1 & 78 & 2 \\
1B & 5 & $<2$ & 12.3 & 6.1 & 100 & 2 \\
1C & 4.7 & 4 & 12.9 & 6.3 & 90 & 2.1 \\
1D & 5 & $<2$ & 12.9 & 6.3 & $<5$ & 2.1 \\
1E & 3.9 & 22 & 12.9 & 6.2 & $<5$ & 2.1 \\
2 & 4.5 & 6 & 5.4 & 5.8 & 253 & 4.1 \\
3 & 3.8 & 5 & 9 & 5.3 & 88 & 3 \\
4 & 26.5 & 21 & 5.1 & 5.4 & 1058 & 3.9 \\
\hline
\end{tabular}




\section{Histology and electron microscopy}

Skin samples with visible white nodules were fixed in $5 \%(\mathrm{v} / \mathrm{v})$ phosphate-buffered formalin, processed by routine methods, sectioned at $5 \mathrm{~mm}$, and stained with hematoxylin and eosin (H\&E). For TEM samples, white nodules were removed from the fish using a scalpel and fixed in glutaraldehyde. Semi-thin sections were stained with toluidine blue; ultrathin sections were contrasted with lead acetate.

\section{Virological analysis: cell culture}

Perch displaying white nodules sampled from Lake 1 during the spring (2012) were aseptically dissected for the collection of skin (nodules) and internal organ tissues (liver, kidney spleen, and brain). Individual tissues were placed in a Whirl-Pak bag, weighed, and homogenized with the use of a stomacher (Seward Stomacher 80 Biomaster Lab System) or pressed with a wooden rolling pin. Hank's Balanced Salt Solution (Gibco) was added to prepare a $2 \%$ tissue homogenate, which was centrifuged at $2500 \times g$ for $15 \mathrm{~min}$ at $4^{\circ} \mathrm{C}$. Clarified supernatant was passed through a $0.45 \mu \mathrm{m}$ low-protein binding membrane filter (Nalgene) and inoculated onto duplicate monolayers of one or multiple cell lines, including epithelioma papulosum cyprini (EPC) (Fijan et al. 1983, Winton et al. 2010), koi fin-1 (KF-1) (Hedrick et al. 2000), fathead minnow (FHM) (Gravell \& Malsberger 1965), common carp brain (CCB) (Neukirch et al. 1999), rainbow trout gonad-2 (RTG-2) (Wolf \& Quimby 1962), Chinook salmon embryo-214 (CHSE-214) (Fryer et al. 1965, Lannan et al. 1984), grunt fin (GF) (Clem et al. 1961), bluegill fry-2(BF-2) (Wolf et al. 1966), white sturgeon skin (WSSK-1) (Hedrick et al. 1991a), white sturgeon spleen-2 (WSS-2) (Hedrick et al. 1991b), burbot embryo fibroblast-1 (BEF-1) (Polinski et al. 2010), and snakehead spleen (SHS) (Lio-Po et al. 1999). Inoculated cell cultures were incubated at temperatures ranging from 15 to $22^{\circ} \mathrm{C}$. After inoculation, cultures were monitored for cytopathic effects (CPE) for 14 to $21 \mathrm{~d}$. All were subsequently passed onto duplicate cell cultures and monitored for 14 to $21 \mathrm{~d}$, after which select samples were placed onto FHM cells and monitored for an additional 14 to $21 \mathrm{~d}$.

\section{Virological analysis: PCR and sequencing}

DNA was extracted from ethanol-preserved skin tissues using the DNeasy Blood and Tissue Kit according to the manufacturer's protocol (QIAGEN). PCR was performed using degenerate primers targeting the DNA polymerase gene of large DNA viruses and adenoviruses (Hanson et al. 2006). Briefly, $3 \mu \mathrm{l}$ of DNA extract was added to $22 \mu \mathrm{l}$ of master mix containing $0.2 \mu \mathrm{M}$ degenerate herpesvirus forward (5'-CGG AAT TCT AGA YTT YGC NWS NYT NTA YCC-3') and degenerate reverse (5'CCC GAA TTC AGA TCT CNG TRT CNC CRT A-3') primers, $1.5 \mathrm{mM} \mathrm{MgCl}_{2}, 0.2 \mathrm{mM}$ dNTPs, $1 \times$ PCR buffer and 0.625 U Platinum Taq Polymerase (Invitrogen). Thermocycling conditions were $2 \mathrm{~min}$ at $94^{\circ} \mathrm{C}$, 35 cycles of $30 \mathrm{~s}$ at $94^{\circ} \mathrm{C}, 2 \mathrm{~min}$ at $45^{\circ} \mathrm{C}$, and $3 \mathrm{~min}$ at $72^{\circ} \mathrm{C}$ followed by 4 min extension at $72^{\circ} \mathrm{C}$. PCR products were visualized on a $1.5 \%$ agarose gel containing $0.2 \times$ SYBR $^{\circledR}$ Safe DNA gel stain (Invitrogen). PCR products were purified using ExoSAP-IT ${ }^{\circledR}$ (Affymetrix) according to the manufacturer's protocol. A total of $2 \mu \mathrm{l}$ of purified product was added to $8 \mu \mathrm{l}$ BigDye ${ }^{\circledR}$ Terminator (BDT) v3.1 cycle sequencing reactions (Applied Biosystems) containing $1 \times$ BDT Buffer, $0.16 \mu \mathrm{M}$ primer and $1 \mu \mathrm{l}$ BDT Ready Reaction Mix. Sequencing primers were the same as those used to amplify the product. Sequencing reaction conditions were $1 \mathrm{~min}$ at $96^{\circ} \mathrm{C}$, and 24 cycles of $10 \mathrm{~s}$ at $96^{\circ} \mathrm{C}, 5 \mathrm{~s}$ at $50^{\circ} \mathrm{C}$, and $4 \mathrm{~min}$ at $60^{\circ} \mathrm{C}$. Sequencing products were purified using the DyeEx 2.0 Spin Kit (QIAGEN) and run on a 3130xl Genetic Analyzer (Applied Biosystems). Sequencing analysis software (v.5.2, Applied Biosystems) was used for base calling and sequences were edited with Sequencher software (v.5.1, Gene Codes Corporation). Following the removal of primer sequences, the consensus nucleotide sequence was used to query the NCBI protein database using the BLASTX algorithm (Altschul et al. 1990).

\section{Genomic sequencing, phenetic analysis, and phylogenetic analysis}

As PCR amplification provided only partial nucleotide sequence of the DNA polymerase gene, additional coverage of the viral genome was obtained through next-generation sequencing. A DNA library was generated from an infected tissue using a TruSeq DNA HT Kit according to the manufacturer's instruction and was paired-end sequenced using a v3 chemistry 600 cycle kit on a MiSeq platform (Illumina). The de novo assembly of 4932880 paired-end reads was performed in SPAdes (Bankevich et al. 2012) and the resulting contigs were screened against a proprietary alloherpesvirus database using 
BLASTX with an E-value cutoff of $<1 \times 10^{-1}$. The analysis produced 4 contigs with lengths of $37718,38747,63122$, and $97445 \mathrm{bp}$, with significant sequence homology to known alloherpesviruses. Open reading frames (ORFs) coding the complete DNA polymerase and terminase genes of the European perch herpesvirus were (Fig. 1) identified from these contigs and used as queries in the BLASTP searches against the NCBI GenBank non-redundant (nr) protein sequence database to find appropriate alloherpesviruses for the phylogenetic and phenetic analyses (Table 3). As some viruses had partial sequence only, subsequent comparisons involved only the region of sequence shared among all taxa. The partial amino acid sequences of the DNA polymerase and terminase genes were then aligned in MAFFT (Katoh et al. 2005) and concatenated in Geneious (Biomatters). The final dataset contained 257 amino acid (AA) characters (including gaps) and the maximum likelihood phylogenetic tree was constructed using IQTREE (http://iqtree.cibiv.univie.ac.at/) (Nguyen et al. 2015) with default parameters. For phenetic analyses, the aligned partial AA sequences of the DNA polymerase (150 AA characters including gaps) and terminase (exon 2; 101 AA characters including gaps) genes were compared to other alloherpesviruses using the sequence demarcation tool (Muhire et al. 2014). The complete nucleotide sequences of DNA polymerase and terminase (exon 2) genes were deposited in GenBank under accession numbers MG570129 and MG570130, respectively.

\section{RESULTS}

\section{Spatial and temporal occurrence of white nodules in perch}

A proportion of European perch sampled from lakes in central Finland exhibited white nodules on their skin (Fig. 2). The large oligotrophic lake (Lake 1) had the highest percentage of fish with white nodules. Of the sampled perch, 39\% were positive in 1997 and $34 \%$ in 1998. Lake 2 had the lowest prevalence with only $10 \%$ of fish bearing nodules for each year sampled. Lake 3 had $31 \%$ of sampled fish containing white nodules in 1997 but only $12 \%$ in 1998 and no nodules were observed on fish sampled in Lake 4. Differences in the preva- lence of nodules were not statistically significant between lakes and sample years (Wilcoxon matched pairs test; $z=-1.153, \mathrm{p}=0.249$ ). Within Lake 1 , nodules were found commonly at all 5 sites in both years (Fig. 3A). At Sites A, D, and E there were variations in the number of nodules found in each year, but the nodule counts in sites $\mathrm{B}$ and $\mathrm{C}$ were unchanged. There were no significant differences found in the prevalence between sites within a single year $\left(\chi^{2}=5.704, \mathrm{p}=0.222\right.$ in 1997 and $\chi^{2}=$ $3.298, \mathrm{p}=0.509$ in 1998). Fish with the highest number of nodules (>30 fish ${ }^{-1}$ ) were found in Lake 1 for both sample years. All fish in Lake 3 had fewer than 10 nodules fish ${ }^{-1}$ in both years, as did fish in Lake 2 in 1998 (Fig. 3B). For both sample years, the occur-

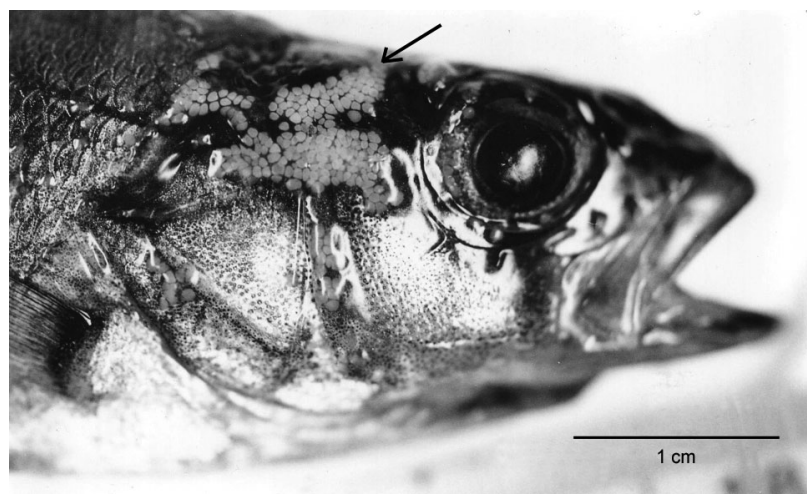

Fig. 2. Aggregation of nodules on the dorsal cranial portion of European perch Perca fluviatilis collected in spring at lakes in Central Finland 

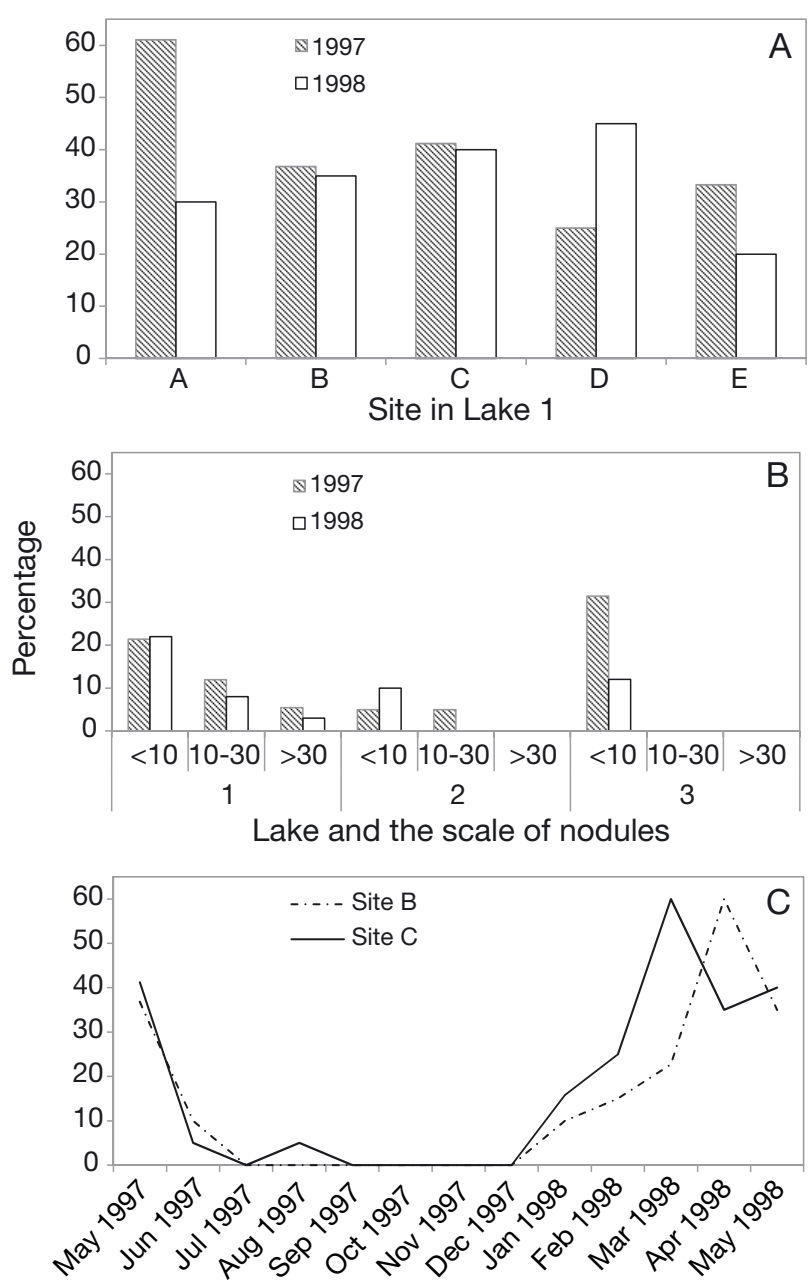

Fig. 3. (A) Prevalence of nodules on European perch Perca fluviatilis collected from 5 sites (A-E) in Lake 1 (see Fig. 1) during May 1997 and 1998; (B) proportion of perch with <10, $10-30$ or $>30$ nodules ind ${ }^{-1}$ counted as $\%$ of all fish studied in May of 1997 and 1998 from Lakes 1, 2, and 3; and (C) seasonal variation in the prevalence of nodules on perch collected at Sites B and C at Lake 1

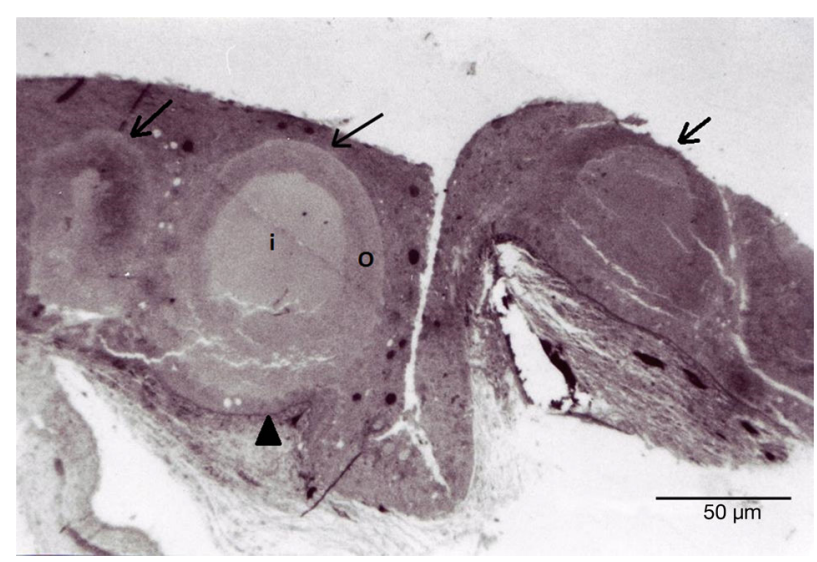

rence of nodules varied considerably throughout the year at Sites B and C in Lake 1. The disease was absent from July to December, except for 1 infected fish found in August at Site C. Peak values were found in March at Site C and in April at Site B in 1998 (Fig. 3C). When pooling all monthly samples by site, no statistical difference was found in the prevalence of nodules between Sites B and C (14.6 and $\left.17.5 \% ; \chi^{2}=0.770, \mathrm{p}=0.380\right)$.

\section{Gross pathology and histopathology}

White nodules on the skin of the perch were $\leq 1 \mathrm{~mm}$ in diameter. They were hard, could not be scraped off using a knife, and were well-defined with a distinct border between the nodules and the surrounding skin. Nodules were found on skin with and without scales and were found individually or in aggregates.

Histologically, the nodules appeared as roundish or ellipsoid structures located within the epidermis above the basement membrane (Fig. 4). Each of these structures appears to consist of one enlarged cell ranging in size from 27 to $170 \mu \mathrm{m}$ in diameter. The structures contain an outer rim (approximately 10 to $30 \mu \mathrm{m}$ thick) that is homogeneous hyalinic and slightly acidophilic whereas the inner part is filled with more loosely arranged granular material that is also slightly acidophilic or partially basophilic. All structures appeared separate with no confluence of cells and all appeared intact with no signs of rupture. Neighboring cells also appeared intact yet in some instances were compressed. There were no signs of inflammation or cellular infiltration.

TEM showed infected cells filled with loosely arranged organelles such as mitochondria, tubular structures of the endoplasmic reticulum, small empty vesicles, some glycogen granules, and the presence of virus-like particles in different stages of development within the nucleus and cytoplasm (Figs. 5 \& 6). Viral capsids within the nucleus were round or hexagonal in shape and existed as empty A-capsids, scaffold-containing B-capsids, and viral genomic DNA-containing C-capsids that were evident by the electron-dense inner core (Fig. 6).

Fig. 4. Section through nodules (arrows) above the basement membrane (arrowhead) within the epidermis of an infected European perch Perca fluviatilis. Nodules display a hyalinic and slightly acidophilic outer rim (o) surrounding a slightly acidophilic or partially basophilic inner core (i) 


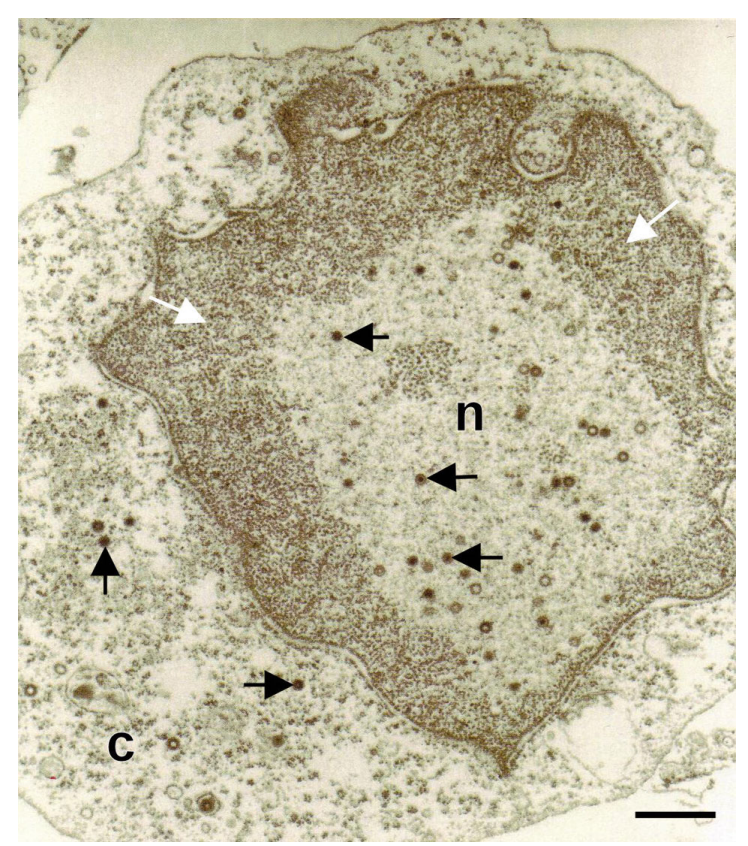

Fig. 5. Electron micrograph of herpesvirus particles in the nucleus (n) and cytoplasm (c) of an infected cell taken from skin of a European perch Perca fluviatilis. White arrows: margination of chromatin in the infected nucleus. Scale bar $=1 \mu \mathrm{m}$

\section{Virology: cell culture and PCR amplification}

Cell cultures inoculated with pooled tissues from affected fish did not have sustained CPE. Nonconspicuous CPE was observed sporadically in a few cell lines. This included enlarged cells (BF-2 + EPC), spindly cells (BEF-1) and vacuolated cells (RTG-2). Nevertheless, upon passing original inocula (at most 2 times) suspect CPE was not observed.

As the particles observed through TEM most closely resembled a herpesvirus, a degenerate PCR targeting a conserved region of the polymerase gene of large DNA viruses (Hanson et al. 2006) was performed. The PCR generated an amplicon (approximately $520 \mathrm{bp}$ ) in 5 of 5 perch skin tissues tested (data not shown). A BLASTX search of the $432 \mathrm{bp}$ (primers removed) nucleotide sequence generated from the PCR product showed the highest identity with alloherpesviruses (E-value $<0.001$ ), notably gadid herpesvirus 1 (GaHV1), acipenserid herpesvirus 2 (AciHV2), ictalurid herpesvirus 1 and 2 (IcHV1, IcHV2), and salmonid herpesvirus 1 (SalHV1).

\section{Phenetic and phylogenetic analyses}

The maximum likelihood analysis of the concatenated partial DNA polymerase and terminase gene sequences produced a well-supported tree (Fig. 7). The European perch herpesvirus (denoted as Percid herpesvirus 2; PeHV2) grouped closely to the Alloherpesviridae species infecting salmonid, ictalurid, acipenserid (acipenserid herpesvirus 2, AciHV2), and esocid (esocid herpesvirus 1, EsHV1) fishes. The phenetic analyses of the PeHV2 partial DNA polymerase and terminase deduced $\mathrm{AA}$ sequences showed identities ranging from 34.6 to $63.9 \%$ and 39.6 to $59.4 \%$ to other alloherpesviruses, respectively (Table 4).

\section{DISCUSSION}

An alloherpesvirus infection was associated with the presence of white nodules on the skin of European perch in Finland. TEM revealed abundant viral particles displaying a hexagonal nucleocapsid with an inner electron-dense core in the nucleus, and cytoplasmic particles displaying an outer lipid envelope characteristic of herpesviruses. Phylogenetic analysis revealed the European perch herpesvirus to be a unique species most closely related to members of the genus Ictalurivirus (Fig. 7).

Generally, herpesviruses are considered either lymphotrophic or neurotrophic, yet the precise

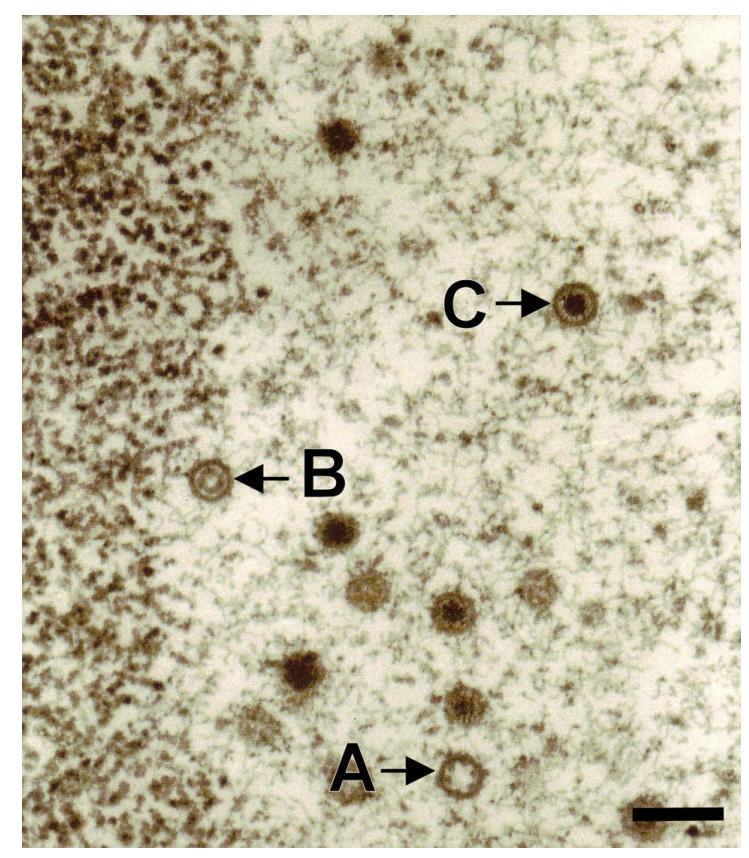

Fig. 6. Infected cell nucleus showing the distribution of capsids in different stages of development. Empty A-capsid, scaffold-containing B-capsid, and viral genomic DNAcontaining $\mathrm{C}$-capsid are denoted with $\mathrm{A}, \mathrm{B}$, and $\mathrm{C}$ arrows, respectively. Scale bar $=250 \mathrm{~nm}$ 


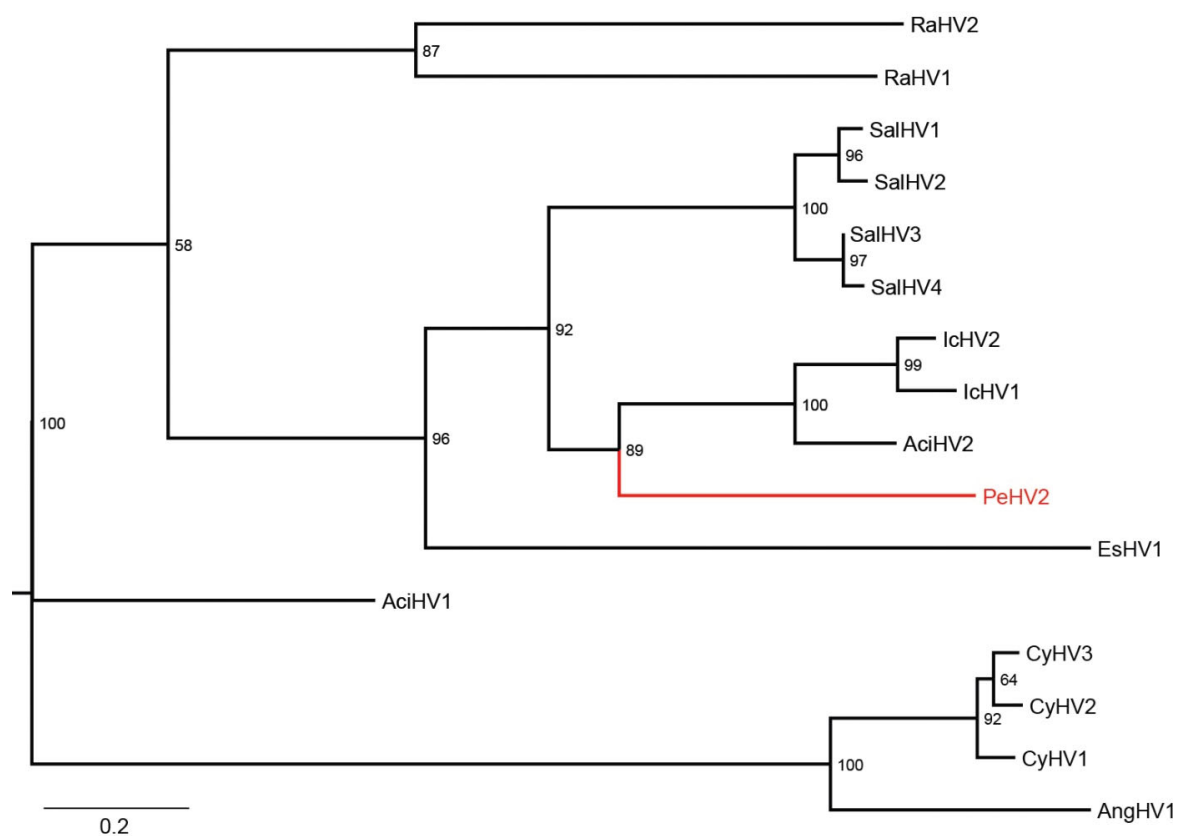

Fig. 7. Phylogram displaying the relationship of percid herpesvirus 2 (PeHV2) to other alloherpesviruses based on the concatenated partial amino acid (AA) sequences of the DNA polymerase and terminase (exon 2) genes (257 AA characters including gaps). The maximum likelihood tree was generated using 1000 bootstraps with values $>70$ included above each node. Branch lengths are based on the number of inferred substitutions, as indicated by the scale bar. See

Table 3 for virus abbreviations

pathogenesis of most herpeseviruses remains unresolved. A feature that appears key to their survival is their ability to establish life-long latent infections where the end-target tissue varies dependent upon virus. To date, many fish herpesviruses demonstrate an affinity towards the epithelium, causing histological changes including epidermal necrosis, hypertrophy, hyperplasia, and in some cases neoplasia (Hanson et al. 2011, 2016). The European perch herpesvirus identified herein appears to follow this affinity for epithelial cells by its association with hypertrophied skin cells, presenting as white nodules. The gross appearance of the white nodules on the skin of the infected European perch share a resemblance to the raised skin lesion in Pacific cod infected with Pacific cod herpesvirus (McArn et al. 1978, McCain et al. 1979) and to the flat, granular, bluish-white skin lesion (blue-spot disease) in northern pike and muskellunge Esox masquinongy infected with pike herspesvirus (Yamamoto et al. 1984, Margenau et al. 1995, Freitas et al. 2016). Moreover, the observation of an enlarged hyperchromatic nucleus and granular cytoplasm in the perch herpesvirus-infected epidermal cells is consistent with other fish herpesvirus infections.

The prevalence of white nodule disease averaged $23 \%$ (range 10-39\%), which falls within the prevalence range reported for blue-spot disease in northern pike and muskellunge in Wisconsin lakes, potentially indicating similarities in transmission efficiencies between the 2 herpesvirus-associated diseases (Margenau et al. 1995). It is curious that the white nodules on European perch were found in only 3 of the 4 lakes sampled despite the connectivity of the lakes. Water drains from Lake 4 to Lake 1 and, theoretically, perch can migrate from lake to lake; however, such migrations have not been observed (K. Leskisenoja unpubl. data). Population fragmentation and limited dispersal capacity of host fishes have been shown as major factors restricting parasite communities in freshwater fishes (Kennedy et al. 1986, Esch et al. 1988, Valtonen et al. 1997, 2003). However, it might also be possible that the lack of white nodules on perch in Lake 4 may simply be due to different environmental conditions as compared to Lakes 1, 2, and 3. For instance, Lake 4 has a higher iron content, is more eutrophic, and is more quickly depleted of oxygen due to a higher COD. Additional studies will be required to determine if the absence of skin nodules reflects an absence of the presumed causative agent, i.e. herpesvirus infection, and/or unfavorable environmental conditions.

The pathogenesis of white nodule disease is unknown; however, formation of the white aggregates may be temperature-dependent as a prominent seasonal occurrence was observed in our study. White nodules appeared in late winter to early spring when perch were preparing to spawn, but were almost absent when fish were examined after the spawning season when water temperature was considerably warmer. Interestingly, the coinciding occurrence of proliferative skin lesion with spring spawning appears to be a common phenomenon of many herpesvirus infections. For instance, the 


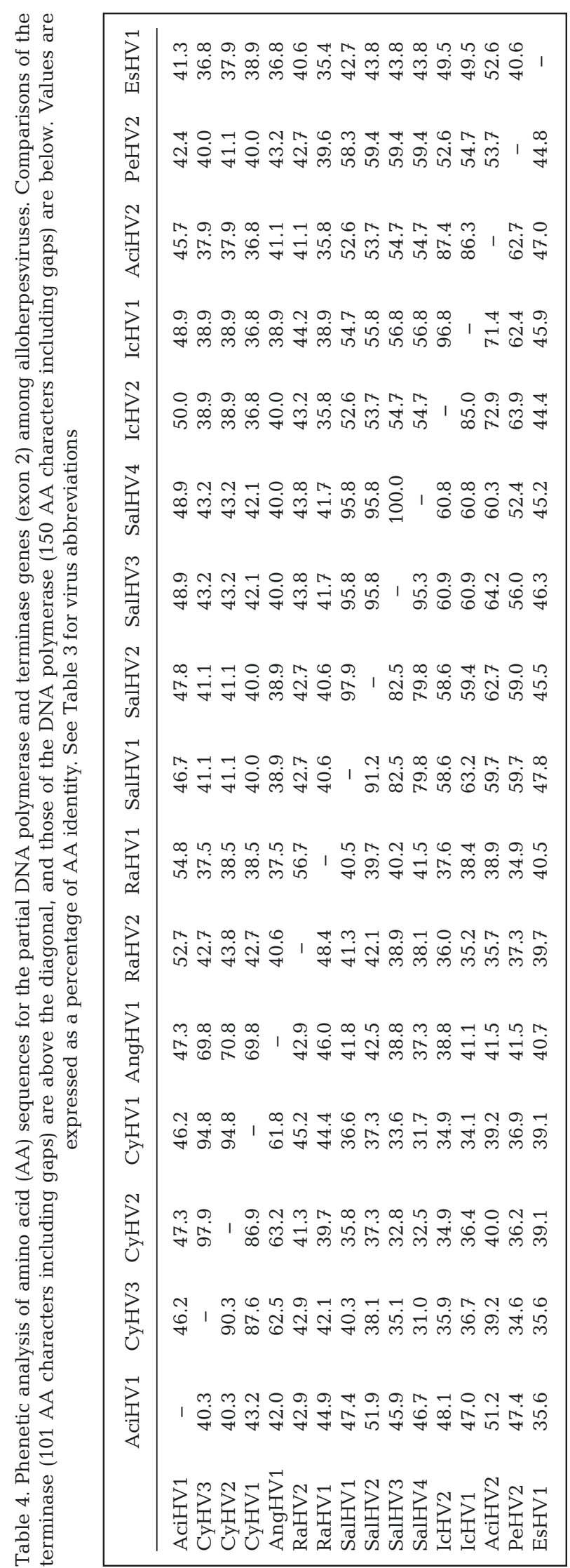

appearance of herpesvirus-induced proliferative skin lesions during spring spawning has been reported in European smelt (Anders \& Möller 1985), walleye (Bowser et al. 1988), northern pike (Freitas et al. 2016), and rainbow smelt (Herman et al. 1997). Although the exact explanation for the seasonal occurrence of the white nodules remains unknown, there is the potential that the perch herpesvirus is exploiting a depressed immune response brought about by lower spring water temperatures and/or stressful spawning conditions as has been described in common carp infected with CyHV1 (Wolf 1988) or CyHV-3 (Uchii et al. 2011). The reduction of visible skin nodules on the perch during the warmer water months suggests a potential regression of skin growths, yet further studies are required to understand the relationship of clinical disease with virus infection, latency, and recrudescence.

Isolation of the European perch herpesvirus would facilitate challenge studies to fulfill Koch's postulates and truly establish whether the epithelial lesions are viral-induced. In our study, attempts at culturing the perch herpesvirus were unsuccessful; however, it is worthwhile noting that a cell line originating from European perch was unavailable at the time the viral isolation assays were performed. As herpesviruses often exhibit a high level of host specificity, it would be prudent in future studies to attempt isolation in a cell line that originates from European perch, or at least from a species in the family Percidae such as the walleye ovary (WO) cell line that was used in the isolation of Percid herpesvirus 1 from infected walleye (Kelly et al. 1983). In addition to using cell lines of related host species, temperature is a factor worth consideration in the permissibility of culturing the perch herpesvirus on cell lines. White nodules were evident on one perch in August when water temperature can reach $20^{\circ} \mathrm{C}$, however the highest prevalence of white nodules was observed during winter and spring months when water temperature is below $4^{\circ} \mathrm{C}$. Consequently, as water temperature for these perch is typically cold, it is possible that the $15^{\circ} \mathrm{C}$ temperature used for cell culture may have been non-permissive for this particular virus.

The European perch herpesvirus partial DNA polymerase and terminase gene (exon 2) sequences obtained in our study permitted phenetic and phylogenetic analyses that identified the virus as a novel species within the family Alloherpesviridae. Phenetic analysis revealed the European perch herpesvirus is a genetically distinct taxon exhibiting greatest AA identity to the members of the genus Ictalurivirus, including IcHV1, IcHV2, AciHV2 
(Table 4). Likewise, phylogenetic analysis based on the concatenated partial DNA polymerase and terminase sequences inferred the European perch herpesvirus as a branch grouping as the sister group to the ictaluriviruses (Fig. 7). Due to its unique standing among the family Alloherpesviridae, we propose the formal species designation of Percid herpesvirus 2 to be considered for approval by the International Committee on Taxonomy of Viruses.

It is unclear what, if any, impact the perch herpesvirus infections have on the European perch populations in our study. It is worth noting that despite the broad distribution and high prevalence of white nodules on European perch, no mortality events or significant declines in the populations were noted over the course of the study, suggesting that under natural conditions the populations usually survive the disease. Most herpesvirus infections result in unapparent or mild disease in natural conditions, yet herpesviruses can be highly pathogenic in environments such as aquaculture where virus transfer is facilitated by high densities of naïve hosts. For instance, herpesviruses including channel catfish virus, Oncorhynchus masou virus, and koi herpesvirus have all caused devastating disease in aquaculture (Hanson et al. 2016). As European perch are increasingly being farmed (Toner et al. 2008), a greater understanding of the pathogens infecting this species is crucial to the development of a sustainable industry. With the potential for herpesviruses to cause severe disease in an aquaculture setting, additional studies are warranted to understand the virulence of this novel alloherpesvirus in European perch.

Acknowledgements. This study was facilitated by funding from the Department of Fisheries and Oceans Canada and through funding to K.L. from the Fisheries Region of Kuhmoinen. The authors thank Rudolf Hoffmann and Theresia Fischer-Scherl at the Institut für Zoologie und Hydrobiologie, Munich, Germany for their assistance with histology and TEM, Mrs. S. and Mr. E. Leskisenoja for fish catching, Lynden Gross for review of the manuscript, and Gary Meyer for assistance with figures.

\section{LITERATURE CITED}

Altschul SF, Gish W, Miller EW, Myers E, Lipman DJ (1990) Basic local alignment search tool. J Mol Biol 215:403-410 Anders K (1989) Lymphocystis disease of fishes. In: Ahne W, Kurstak E (eds) Viruses of lower vertebrates. Springer, Berlin, p 141-160

Anders K, Möller H (1985) Spawning papillomatosis of smelt, Osmerus eperlanus L., from the Elbe estuary. $\mathrm{J}$ Fish Dis 8:233-235
Aoki T, Hirono I, Kurokawa K, Fukuda H and others (2007) Genome sequences of three koi herpesvirus isolates representing the expanding distribution of an emerging disease threatening koi and common carp worldwide. J Virol 81:5058-5065

Bankevich A, Nurk S, Antipov D, Gurevich AA and others (2012) SPAdes: a new genome assembly algorithm and its applications to single-cell sequencing. J Comput Biol 19:455-477

* Bowser PR, Wolfe MJ, Forney JL, Wooster GA (1988) Seasonal prevalence of skin tumors from walleye (Stizostedion vitreum) from Oneida Lake, New York. J Wildl Dis 24:292-298

Bush AO, Lafferty KD, Lotz JM, Shostak AW (1997) Parasitology meets ecology on its own terms: Margolis et al. revisited. J Parasitol 83:575-583

* Clem LW, Moewus L, Sigel MM (1961) Studies with cells from marine fish in tissue culture. Proc Soc Exp Biol Med 108:762-766

Craig JF (2000) Parasites and diseases. In: Percid fishes: systematics, ecology and exploitation. Blackwell Science, Oxford, p 124-146

Crockford M, Jones JB, Crane MSJ, Wilcox GE (2005) Molecular detection of a virus, Pilchard herpesvirus, associated with epizootics in Australasian pilchards Sardinops sagax neopilchardus. Dis Aquat Org 68:1-5

*Doszpoly A, Karaseva TA, Waltzek TB, Kalabekov IM, Shchelkunov IS (2013) Atlantic salmon papillomatosis in Russia and molecular characterization of the associated herpesvirus. Dis Aquat Org 107:121-127

*Doszpoly A, Kalabekov IM, Breyta R, Shchelkunov IS (2017) Isolation and characterization of an atypical Siberian sturgeon herpesvirus strain in Russia: Novel North American Acipenserid herpesvirus 2 strain in Europe? J Fish Dis 40:1363-1372

Esch GW, Kennedy CR, Bush AO, Aho JM (1988) Patterns in helminth communities in freshwater fish in Great Britain: alternative strategies for colonization. Parasitology 96:519-532

Fijan N, Sulimanovi D, Bearzotti M, Mužini D and others (1983) Some properties of the epithelioma papulosum cyprini (EPC) cell line from carp Cyprinus carpio. Ann Inst Pasteur Virol 134:207-220

Freitas JT, Subramaniam K, Kelley KL, Marcquenski S, Groff J, Waltzek TB (2016) Genetic characterization of esocid herpesvirus 1 (EsHV1). Dis Aquat Org 122:1-11

Fryer JL, Yusha A, Pilcher KS (1965) The in vitro cultivation of tissue and cells of Pacific salmon and steelhead trout. Ann N Y Acad Sci 126:566-586

* Glenney GW, Barbash PA, Coll JA (2016) Initial detection and molecular characterization of Namaycush herpesvirus (salmonid herpesvirus 5) in lake trout. J Aquat Anim Health 28:46-55

* Gravell M, Malsberger RG (1965) A permanent cell line from the fathead minnow (Pimephales promelas). Ann N Y Acad Sci 126:555-565

*Hanson LA, Rudis MR, Vasquez-Lee M, Montgomery RD (2006) A broadly applicable method to characterize large DNA viruses and adenoviruses based on the DNA polymerase gene. Virol J 3:28

*Hanson L, Dishon A, Kotler M (2011) Herpesviruses that infect fish. Viruses 3:2160-2191

Hanson L, Doszpoly A, van Beurden SJ, Viadanna P, Waltzek T (2016) Alloherpesviruses of fish. In: Kibenge FSB, Godoy MG (eds) Aquaculture virology. Academic Press, London, p 153-172 
Hedrick RP, Groff JM, McDowell TS (1991a) Isolation of an epitheliotropic herpesvirus from white sturgeon (Acipenser transmontanus). Dis Aquat Org 11:49-56

Hedrick RP, McDowell TS, Rosemark R, Aronstein D, Lannan CN (1991b) Two cell lines from white sturgeon. Trans Am Fish Soc 120:528-534

Hedrick RP, Gilad O, Yun S, Spangenberg JV and others (2000) A herpesvirus associated with mass mortality of juvenile and adult koi, a strain of common carp. J Aquat Anim Health 12:44-57

Hellberg H, Koppang EO, Tørud B, Bjerkås I (2002) Subclinical herpesvirus infection in farmed turbot Scophthalmus maximus. Dis Aquat Org 49:27-31

* Herman RL, Burke CN, Perry S (1997) Epidermal tumors of rainbow smelt with associated virus. J Wildl Dis 33: 925-929

ICTV (2012) Order Herpesvirales. In: King AMQ, Adams MJ, Carstens EB, Lefkowitz EJ (eds) Virus taxonomy: classification and nomenclature of viruses: ninth report of the International Committee on Taxonomy of Viruses. Elsevier, San Diego, CA, p 99-123

Jakob NJ, Kehm R, Gelderblom HR (2010) A novel fish herpesvirus of Osmerus eperlanus. Virus Genes 41:81-85

Katoh K, Kuma K, Toh H, Miyata T (2005) MAAFT version 5: improvement in accuracy of multiple sequence alignment. Nucleic Acids Res 33:511-518

Kelly RK, Nielson O, Mitchell SC, Yamamoto T (1983) Characterization of Herpesvirus vitreum isolated from hyperplastic epidermal tissue of walleye, Stizostedion vitreum vitreum (Mitchill). J Fish Dis 6:249-260

Kennedy CR, Budh AO, Aho JM (1986) Patterns in helminth communities: Why are birds and fish different? Parasitology 93:205-215

Koli L (1990) Suomen kalat. Werner Söderström Osakeyhtiö, Helsinki

Lannan CN, Winton JR, Fryer JL (1984) Fish cell lines: establishment and characterization of nine cell lines from salmonids. In Vitro 20:671-676

Lio-Po GD, Traxler GS, Albright LJ (1999) Establishment of cell lines from catfish (Clarias batrachus) and snakeheads (Ophicephalus striatus). Asian Fish Sci 12:345-349

Marcos-Lopez M, Waltzek TB, Hedrick RP, Baxa DV and others (2012) Characterization of a novel alloherpesvirus from Atlantic cod (Gadus morhua). J Vet Diagn Invest 24: 65-73

Margenau TL, Marcquenski SV, Rasmussen PW, MacConnell E (1995) Prevalence of blue spot disease (esocid herpesvirus-1) on northern pike and muskellunge in Wisconsin. J Aquat Anim Health 7:29-33

* Matthews RA (2005) Ichthyophthirius multifiliis Fouquet and ichthyophthiriosis in freshwater teleosts. Adv Parasitol 59:159-241

McArn GE, McCain B, Wellings SR (1978) Skin lesions and associated virus in Pacific cod (Gadus macrocephalus) in the Bering Sea. Fed Proc 37:937

McCain BB, Gronlund WD, Myers MS, Wellings SR (1979) Tumours and microbial diseases of marine fishes in Alaskan waters. J Fish Dis 2:111-130

Morrison CM, Leggiadro CT, Martell DJ (1996) Visualization of viruses in tumors of rainbow smelt Osmerus mordax. Dis Aquat Org 26:19-23

Muhire BM, Varsani A, Martin DP (2014) SDT: a virus classification tool based on pairwise sequence alignment and identity calculation. PLOS ONE 9:e108277
Neukirch M, Boettcher K, Bunnajirakul S (1999) Isolation of a virus from koi with altered gills. Bull Eur Assoc Fish Pathol 19:221-224

Nguyen LT, Schmidt HA, von Haeseler A, Minh BQ (2015) IQ-TREE: a fast and effective stochastic algorithm for estimating maximum-likelihood phylogenies. Mol Biol Evol 32:268-274

Palmer LJ, Hogan NS, van den Heuvel MR (2012) Phylogenetic analysis and molecular methods for the detection of lymphocystis disease virus from yellow perch, Perca flavescens (Mitchell). J Fish Dis 35:661-670

Plumb JA, Hanson LA (2011) Health maintenance and principal microbial diseases of cultured fishes, $3^{\text {rd }}$ edn. Wiley-Blackwell, Ames, IA

* Polinski MP, Drennan JD, Batts WN, Ireland SC, Cain KD (2010) Establishment and partial characterization of a cell line from burbot Lota lota maculosa: susceptibility to IHNV, IPNV and VHSV. Dis Aquat Org 90:15-23

Toner D, Rougeot C, Fontaine P, Kestemont P and others (2008) Farming of Eurasian perch, Vol 1: juvenile production. Aquaculture explained, No. 24. Irish Sea Fisheries Board, Dun Laoghaire

Tribiloustova E (2005) Freshwater fish for European markets. Globefish research programme, Vol 82. FAO, Rome

U Uchii K, Telschow A, Minamoto T, Yamanaka H, Honjo MN, Matsui K, Kawabata Z (2011) Transmission dynamics of an emerging infectious disease in wildlife through host reproductive cycles. ISME J 5:244-251

Valtonen ET, Holmes JC, Koskivaara M (1997) Eutrophication, pollution, and fragmentation: effect on parasite communities in roach (Rutilus rutilus) and perch (Perca fluviatilis) in four lakes in central Finland. Can J Fish Aquat Sci 54:572-585

* Valtonen ET, Holmes JC, Aronen J, Rautalahti I (2003) Parasite communities as indicators of recovery from pollution: parasites of roach (Rutilus rutilus) and perch (Perca fluviatilis) in central Finland. Parasitology 126:S43-S52

*van Beurden S, Engelsma M (2012) Herpesviruses of fish, amphibians and invertebrates. In: Magel GD, Tyring S (eds) Herpesviridae - a look into this unique family of viruses. InTech, London, p 218-242

*van Beurden SJ, Bossers A, Voorbergen-Laarman MHA, Haenen OLM and others (2010) Complete genome sequence and taxonomic position of anguillid herpesvirus 1. J Gen Virol 91:880-887

*Waltzek TB, Kelley GO, Alfaro ME, Kurobe T, Davison AJ, Hedrick RP (2009) Phylogenetic relationships in the family Alloherpesviridae. Dis Aquat Org 84:179-194

*Winton J, Batts W, deKinkelin P, LeBerre M, Bremont M, Fijan N (2010) Current lineages of the epithelioma papulosum cyprini (EPC) cell line are contaminated with fathead minnow, Pimephales promelas, cells. J Fish Dis 33: 701-704

Wolf K (1988) Fish viruses and fish viral diseases. Cornell University Press, Ithaca, NY

*Wolf K, Quimby MC (1962) Established eurythermic line of fish cells in vitro. Science 135:1065-1066

*Wolf K, Gravell M, Malsberger RG (1966) Lymphocystis virus: isolation and propagation in centrarchid fish cell lines. Science 151:1004-1005

* Yamamoto T, Kelly RK, Nielsen O (1984) Epidermal hyperplasias of northern pike (Esox lucius) associated with herpesvirus and C-type particles. Arch Virol 79: 255-272

Submitted: December 5, 2017 ; Accepted: March 27, 2018

Proofs received from author(s): May 10, 2018 